\title{
Comparison of intramuscular betamethasone and oral prednisone in the prevention of relapse of acute asthma
}

\author{
John S Chan $M D^{1}$, Robert L Cowie MD ${ }^{1}$, Gerald C Lazarenko MD ${ }^{2}$, Cinde Little RRT ${ }^{1}$, \\ Sandra Scott RRT ${ }^{1}$, Gordon T Ford MD FCCP ${ }^{1}$ \\ ${ }^{1}$ Division of Respiratory Medicine and ${ }^{2}$ Department of Emergency Medicine, \\ University of Calgary, Calgary, Alberta
}

JS Chan, RL Cowie, GC Lazarenko, C Little, S Scott, GT Ford. Comparison of intramuscular betamethasone and oral prednisone in the prevention of relapse of acute asthma. Can Respir J 2001;8(3):147-152.

OBJECTIVE: To compare the relapse rate after a single intramuscular injection of a long acting corticosteroid, betamethasone, with oral prednisone in patients discharged from the emergency department (ED) for acute exacerbations of asthma.

PATIENTS AND METHODS: Patients with acute exacerbations of asthma who were suitable for discharge from the ED were enrolled in a double-blind, randomized, placebo controlled pilot study. At discharge, patients were randomly assigned to receive either intramuscular betamethasone $12 \mathrm{mg}$ and placebo capsules, or a placebo intramuscular injection and prednisone $50 \mathrm{mg}$ daily for seven days. At days 7 and 21, patients were contacted by telephone to determine relapse. Relapse was defined as an unscheduled visit to a physician for treatment of continuing or worsening symptoms of asthma.

RESULTS: One hundred and seventy-one patients were enrolled, of whom 87 were randomly assigned to the betamethasone group and 84 to the prednisone group. Baseline char- acteristics were matched evenly between the groups, with the exception of asthma duration (15.5 versus 21.2 years, respec- tively) and use of inhaled corticosteroids (46\% versus $64.3 \%$ respectively) $(\mathrm{P}<0.05)$. Using intention-to-treat analysis, the relapse rates for betamethasone and prednisone at day 7 were $14.9 \%$ (13 of 87 patients) and 25\% (21 of 84 patients), respectively $(\mathrm{P}=0.1)$, and at day 21 , the rates were $36.8 \%$ (32 of 87 patients) and $31 \%$ (26 of 84 patients), respectively $(\mathrm{P}=0.4)$. There were no differences in symptom score, peak flows and adverse effects between the two groups at days 7 and 21.

CONCLUSIONS: A single dose of intramuscular betamethasone $12 \mathrm{mg}$ was safe and as efficacious as prednisone in preventing the relapse of acute asthma. There was a trend toward a reduced relapse rate at seven days. In select ED patients discharged for acute asthma, intramuscular betamethasone may be an effective alternative to prednisone.

Key Words: Asthma; Betamethasone; Emergency department; Randomized, controlled trial

\section{Comparaison entre la bétaméthasone intramusculaire et la prednisone orale pour prévenir les rechutes d'asthme aigu}

OBJECTIF : Comparer le taux de rechute après l'injection intramusculaire d'une seule dose d'un corticostéroïde à action voir page suivante 
prolongée, la bétaméthasone, à celui enregistré après l'administration de prednisone par voie orale chez les patients traités pour une poussée d'asthme et ayant obtenu leur congé du service d'urgence.

PATIENTS ET MÉTHODE : Des patients traités au service d'urgence pour une poussée d'asthme, puis renvoyés au domicile ont participé à un essai pilote, mené contre placebo, à double insu, avec hasardisation. Au moment du congé, les patients ont reçu au hasard ou bien une injection intramusculaire de bétaméthasone de $12 \mathrm{mg}$ et des capsules placebo ou bien une injection intramusculaire placebo et des capsules de prednisone de $50 \mathrm{mg}$ à prendre tous les jours pendant sept jours. Au bout du $7^{\mathrm{e}}$ et du $21^{\mathrm{e}}$ jour, les chercheurs ont communiqué avec les patients pour savoir s'ils avaient fait des rechutes. On entendait par rechute toute consultation médicale non prévue pour persistance ou aggravation des symptômes d'asthme.

RÉSULTATS : Cent soixante et onze patients ont participé à l'étude : 87 ont reçu au hasard de la bétaméthasone, 84, de la prednisone. Il y a eu répartition égale des caractéristiques de base entre les deux groupes, à l'exception de la durée de l'asthme (15,5 ans contre 21,2 respectivement) et de l'utilisation de corticostéroïdes en aérosol ( $46 \%$ contre $64,3 \%$ respectivement) $(\mathrm{P}<0,05)$. Selon l'analyse fondée sur le principe de vouloir traiter, le taux de rechute pour la bétaméthasone et la prednisone au $7^{\mathrm{e}}$ jour a été de $14,9 \%$ (13 patients sur 87 ) et de $25 \%$ (21 patients sur 84$)$ respectivement $(\mathrm{P}=0,1)$ et au $21^{\mathrm{e}}$ jour, de $36,8 \%$ (32 patients sur 87 ) et de $31 \%$ (26 patients sur 84 ) respectivement $(\mathrm{P}=0,4)$. Aucune différence n'a été enregistrée quant à la cote des symptômes, au débit de pointe et aux effets indésirables entre les deux groupes au $7^{\mathrm{e}}$ et au $21^{\mathrm{e}}$ jour.

CONCLUSION : L'injection intramusculaire d'une seule dose de bétaméthasone de $12 \mathrm{mg}$ s'est avérée sûre et aussi efficace que la prednisone pour prévenir les rechutes d'asthme aigu. Une tendance à une réduction du taux de rechute a même été observée au $7^{\mathrm{e}}$ jour. Aussi la bétaméthasone intramusculaire peut-elle remplacer efficacement la prednisone chez les patients sélectionnés, traités pour une poussée d'asthme et renvoyés du service d'urgence.
A cute exacerbations of asthma are a common presentation to emergency departments (EDs). Most patients can be adequately treated and safely discharged home with the appropriate medications and follow-up. Recent studies and a systematic review have shown the benefit of a course of corticosteroids following discharge from the ED in reducing the risk of relapse (1-3). However, the relapse rate at 21 days remains as high as $25 \%$ despite the use of corticosteroids (4).

Patients with asthma who use the ED during acute exacerbations are thought to have high indexes of denial and poor compliance, thus leading to poor control of their disease. Compliance with pulmonary medications has been reported to be as low as $30 \%$ (5). Twelve per cent to $22 \%$ of patients leaving the ED do not fill their prescriptions $(6,7)$. They are often given complex regimens of corticosteroids involving multiple tablets, which may further decrease compliance. A single depot injection of corticosteroid administered at the time of discharge may bypass these compliance issues and lead to a reduction in relapse rates. McNamara and Rubin (8) compared intramuscular methylprednisone with placebo after discharge for acute asthma and found a significant reduction in relapse rates. There are few studies directly comparing intramuscular with oral corticosteroids after exacerbations (9-11).

We undertook this pilot study to compare the relapse rates in patients with acute exacerbations of asthma discharged from the ED who had been given a single intramuscular injection of betamethasone $12 \mathrm{mg} /$ day or prednisone $50 \mathrm{mg} /$ day for seven days. Our primary end point was the relapse rate at days 7 and 21, and secondary end points were symptom score, peak flows and adverse effects.

\section{PATIENTS AND METHODS}

Patients: This randomized, double-blind, controlled clinical trial was conducted at two hospitals in Calgary, Alberta. The EDs of these hospitals provide 24 h coverage in a community of 853,711 people (12). From June 1997 to August 1999, ED physicians were asked to refer patients treated in the ED for acute exacerbations of asthma who were suitable for discharge.

The inclusion criteria were a diagnosis of asthma with an acute exacerbation, being at least 18 years of age, the absence of contraindications to prednisone or betamethasone, and suitability for discharge from the ED. The diagnosis of asthma was made clinically by the ED physician. Patients were excluded if any of the following conditions were present: complicating illnesses (congestive heart failure, chronic obstructive pulmonary disease or other pulmonary conditions); chronic infections; acute bacterial pneumonia; pregnancy or breastfeeding; being a nonresident of Alberta; and current oral corticosteroid use for longer than $24 \mathrm{~h}$.

Written informed consent was obtained from each patient by an ED respiratory therapist. The study was approved by the Conjoint Health Research Ethics Board of the University of Calgary, Calgary, Alberta.

ED protocol: The treatment of the asthma exacerbation was determined by the ED physician and included oxygen, nebulized salbutamol and, in some cases, intravenous or oral corticosteroids. The use of parenteral or oral corticosteroids within $24 \mathrm{~h}$ of enrolment was not considered an exclusion criterion. The decision regarding discharge was made by the ED physician.

The hospital pharmacy provided sequentially numbered, sealed kits that were randomized to contain either an injection of betamethasone $2 \mathrm{~mL}$ (betamethasone sodium phosphate $6 \mathrm{mg}$ and betamethasone acetate $6 \mathrm{mg}$; Celestone Soluspan, Schering Canada Inc, Canada) and seven placebo capsules, or an injection of saline $2 \mathrm{~mL}$ and seven capsules containing prednisone $50 \mathrm{mg}$ each (Novopharm Limited, Canada). Saline was used as the placebo injection because a control solution identical to the betamethasone solution was unavailable.

The dose and duration of use of the prednisone were chosen in accordance with the published clinical practice guidelines of the Canadian Association of Emergency Room Physicians and the Canadian Thoracic Society (13). 


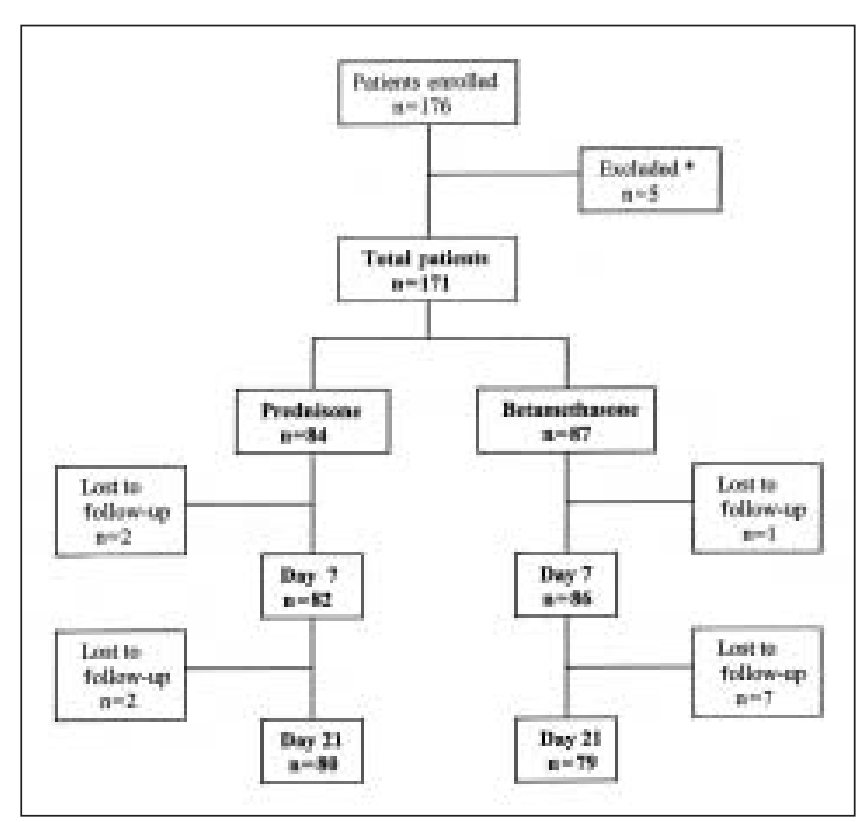

Figure 1) Patient enrolment and follow-up. *Five patients were excluded after random assignment: three patients required hospitalization before discharge from the emergency department; one was discovered to be on chronic oral prednisone; and one refused the injection

These guidelines recommend prednisone $30 \mathrm{mg} /$ day to $60 \mathrm{mg} /$ day for seven to 14 days. Betamethasone was chosen as the depot steroid because of its potent anti-inflammatory effect and long duration of action. The relative antiinflammatory potency of betamethasone to that of prednisone is 25 to 4 , and its half-life is 36 to $72 \mathrm{~h}$ (14).

After consent was obtained, a kit was opened by a nurse who was not involved with the study patient. This nurse drew up the $2 \mathrm{~mL}$ solution and placed a translucent sleeve over the syringe to obscure the medication but to allow the graduations to be seen. The primary nurse involved with the patient was given the covered syringe and capsules, and administered the intramuscular injection. The patients were instructed to take the study capsules daily for the next seven days.

Each patient was given a peak flow meter (Pocketpeak, Hudson Respiratory Care Inc, USA) and instructed on its use. They were asked to record the best of three morning and three evening readings for 21 days.

The discharge instructions were not standardized. Recommendations on the use of current medications including beta2-agonists, inhaled corticosteroids and theophylline were left to the discretion of the treating ED physician. A card containing information on the study and a contact number for the research coordinator was given to each patient.

Data collection: The primary end point was the relapse rate at days 7 and 21. Patients were contacted by telephone on day 7 and day 21 by a study coordinator blinded to the treatment allocation, and asked if they had sought treatment for their asthma since the initial ED visit. Patients were considered lost to follow-up if multiple telephone calls on three separate days were unsuccessful. A relapse was defined as an
TABLE 1

Baseline characteristics: Demographics of 171 patients with acute exacerbations of asthma

\begin{tabular}{lccc}
\hline Characteristic & $\begin{array}{c}\text { Prednisone } \\
(\mathbf{n}=84)\end{array}$ & $\begin{array}{c}\text { Betamethasone } \\
(\mathbf{n}=87)\end{array}$ & $\mathbf{P}$ \\
\hline Age: years (SD) & $32.1(10.7)$ & $31.6(13.1)$ & \\
Sex (\%) & & & \\
$\quad$ Male & $40(48)$ & $37(43)$ & \\
$\quad$ Female & $44(52)$ & $50(57)$ & \\
Mean duration of & $21.2(13.2)$ & $15.5(10.4)$ & $\mathrm{P}=0.002$ \\
$\quad$ asthma (SD) & & & \\
Smoking status (\%) & & & \\
$\quad$ Current & $26(31)$ & $29(34)$ & \\
$\quad$ Former & $28(33)$ & $19(22)$ & \\
$\quad$ Never & $30(36)$ & $38(44)$ &
\end{tabular}

$P$ values given for those less than 0.05

unscheduled visit to the ED, medical clinic or the patient's own family physician for treatment of continuing or worsening symptoms of asthma. A visit to the family physician made after the patient's discharge from the ED for followup was not considered to be a relapse if, at the time of the visit, the patient was asymptomatic or improving, and would not ordinarily have visited a physician. Before unblinding, all instances of suspected relapse were reviewed by two of the investigators.

Patients were also asked about symptoms, peak flows and adverse effects. A simplified asthma symptom score was obtained at days 7 and 21 consisting of shortness of breath, cough, wheeze, activity limitation and sleep disturbance. The patients were asked to give a score of 1 to 10 for each symptom, with 1 indicating the absence of the symptom and 10 indicating the most severe symptom. The best morning and evening peak flow readings were recorded for the 21 days.

Statistical analysis: Continuous variables were reported as the mean \pm SD. The primary analysis was based on the intention-to-treat principle. Two-tailed $t$ tests were used for continuous variables and ${ }^{2}$ analysis for categorical variables. All results were considered significant at $\mathrm{P}<0.05$.

This study was designed as a pilot to ensure that there was no dramatic difference between the two groups, and the ability to show a twofold difference in the relapse rate after asthma exacerbation. A sample size of approximately 180 patients was estimated using the following assumptions: $80 \%$ power and a $95 \% \mathrm{CI}$ to show a difference between relapse rates of $40 \%$ and $20 \%$.

\section{RESULTS}

During the study, 176 patients with acute asthma agreed to participate in the trial. After random assignment, five patients were subsequently excluded: three patients required hospitalization before ED discharge; one was discovered to be on chronic oral prednisone; and one refused the injection (Figure 1).

Of the remaining 171 patients, 84 received prednisone and 87 received betamethasone. At day 7, three patients were lost 
TABLE 2

Baseline characteristics: Asthma history of 171 patients with acute exacerbations of asthma*

\begin{tabular}{lcc}
\hline Characteristic & $\begin{array}{c}\text { Prednisone } \\
(\mathbf{n}=84)\end{array}$ & $\begin{array}{c}\text { Betamethasone } \\
(\mathbf{n}=87)\end{array}$ \\
\hline $\begin{array}{l}\text { Previous oral steroid use (\%) } \\
\text { Previous ED visits (\%) }\end{array}$ & $65(77)$ & $66(76)$ \\
$\quad$ Three & $49(59)$ & $54(62)$ \\
One to three & $29(35)$ & $28(32)$ \\
$\quad$ None & $5(6)$ & $5(6)$ \\
Previous hospitalizations (\%) & & \\
$\quad$ Three & $25(30)$ & $25(29)$ \\
One to three & $25(30)$ & $29(33)$ \\
$\quad$ None & $33(40)$ & $33(38)$ \\
Previous ICU admission (\%) & $14(17)$ & $9(10)$ \\
Previous intubation (\%) & $4(5)$ & $5(6)$ \\
Asthma care (\%) & & \\
Family physician & $58(69)$ & $64(74)$ \\
$\quad$ Respirologist & $9(11)$ & $15(17)$ \\
Peak flow meter (\%) & $39(46)$ & $40(46)$ \\
Peak flow action plan (\%) & $23(27)$ & $30(35)$ \\
\hline
\end{tabular}

$P$ values given are for those less than 0.05. ED Emergency department; ICU Intensive care unit

\section{TABLE 3}

Baseline medications and emergency department (ED) characteristics of patients with acute exacerbations of asthma

\begin{tabular}{|c|c|c|c|}
\hline Characteristic & $\begin{array}{l}\text { Prednisone } \\
(n=84)\end{array}$ & $\begin{array}{c}\text { Betamethasone } \\
(n=87)\end{array}$ & $\mathbf{P}$ \\
\hline \multicolumn{4}{|l|}{ Medication (\%) } \\
\hline $\begin{array}{l}\text { Short acting } \\
\text { beta-agonist }\end{array}$ & $80(95)$ & $84(97)$ & \\
\hline $\begin{array}{l}\text { Long acting } \\
\text { beta-agonist }\end{array}$ & $5(6)$ & $2(2)$ & \\
\hline Inhaled corticosteroid & $54(64)$ & $40(46)$ & 0.02 \\
\hline Theophylline & $3(4)$ & $1(1)$ & \\
\hline $\begin{array}{l}\text { Leukotriene receptor } \\
\text { antagonist }\end{array}$ & $1(1)$ & $2(2)$ & \\
\hline Ipratropium bromide & $4(5)$ & $4(5)$ & \\
\hline Nedocromil & 0 & $1(1)$ & \\
\hline $\begin{array}{l}\text { ED systemic } \\
\text { corticosteroids (\%) }\end{array}$ & $58(69)$ & $68(78)$ & \\
\hline \multicolumn{4}{|c|}{ Initial ED peak expiratory flow rate } \\
\hline Mean (SD) (L/min) & $270(103)$ & $261(104)$ & \\
\hline $\begin{array}{l}\text { \% predicted peak } \\
\text { expiratory flow rate } \\
\text { (SD) }\end{array}$ & $50(17)$ & $50(19)$ & \\
\hline
\end{tabular}

$P$ values given are for those less than 0.05

to follow-up - two in the prednisone group and one in the betamethasone group. By day 21, 12 patients were lost to follow up - four in the prednisone group and eight in the betamethasone group. At the completion of the study, follow-up information was available for 159 patients (93\%).

The primary analysis of relapse rates was based on the 171 appropriately enrolled patients. The baseline characteristics of the two groups are shown in Tables 1, 2 and 3. Patients allo-
TABLE 4

Relapse rates at day 7 and day 21 of patients with acute exacerbations of asthma

\begin{tabular}{lccc}
\hline & $\begin{array}{c}\text { Prednisone } \\
(\mathbf{n}=\mathbf{8 4})\end{array}$ & $\begin{array}{c}\text { Betamethasone } \\
(\mathbf{n}=\mathbf{8 7})\end{array}$ & $\mathbf{P}$ \\
\hline Day 7 (\%) & $21(25)$ & $13(14.9)$ & 0.1 \\
Day 21 $(\%)$ & $26(31)$ & $32(36.8)$ & 0.4 \\
\hline
\end{tabular}

cated to prednisone had a longer duration of asthma (21.2 versus 15.5 years, $\mathrm{P}=0.002$ ) and were more likely to be on regular inhaled corticosteroids (64.3\% versus 46\%, $\mathrm{P}=0.02$ ). Age, sex, smoking status, markers of severity (ED visits, hospitalization, intensive care unit admissions and intubation) and baseline peak flows were similar between the two groups. The use of intravenous or oral steroids in the ED before enrolment did not differ significantly between the two groups.

The relapse rates for the two groups at days 7 and 21 are shown in Table 4. At day 7 in the prednisone group, 19 patients had relapsed and two had been lost to follow-up (21 of 84 [25\%]). In the betamethasone group, 12 patients relapsed and one was lost to follow-up (13 of 87 [14.9\%]). The seven-day relapse rate in the betamethasone group was $60 \%$ of that in the prednisone group, but the difference did not reach statistical significance $(\mathrm{P}=0.1)$.

At day 21 in the prednisone group, 22 patients had relapsed and four were lost to follow-up (26 of 84 [31\%]). In the betamethasone group, 24 had relapsed and eight were lost to follow-up (32 of 87 [36.8\%]). The difference was not statistically significant $(\mathrm{P}=0.4)$.

Secondary outcomes included symptom scores, peak flows and adverse effects. Symptom scores for patients who had not relapsed and were available for follow-up at days 7 and 21 are shown in Table 5. Some patients refused to provide symptom scores. For example, at day 21 in the betamethasone group, 24 patients had relapsed, eight were lost to follow-up and seven did not provide symptom scores; therefore, scores are provided for 48 patients or $55 \%$ of the original 87 randomly assigned patients. No significant differences were seen between the two groups at either day 7 or day 21 .

The mean peak flow for weeks 1 and 3 for each group was calculated using the average of the best morning and evening readings available from patients who had not relapsed, and with at least five readings during the week (Table 6). There were no significant differences between the two groups.

All of the patients randomly assigned to receive prednisone reported taking all seven capsules; $95 \%$ of the patients in the betamethasone group completed the entire course. Fifty-six per cent of the prednisone group and $61 \%$ of the betamethasone group reported no adverse effects $(\mathrm{P}=0.5)$. The most common adverse effects reported were insomnia and nausea (prednisone: five of 84 and six of 84 patients, respectively; betamethasone: nine of 87 and seven of 87 patients, respectively). 


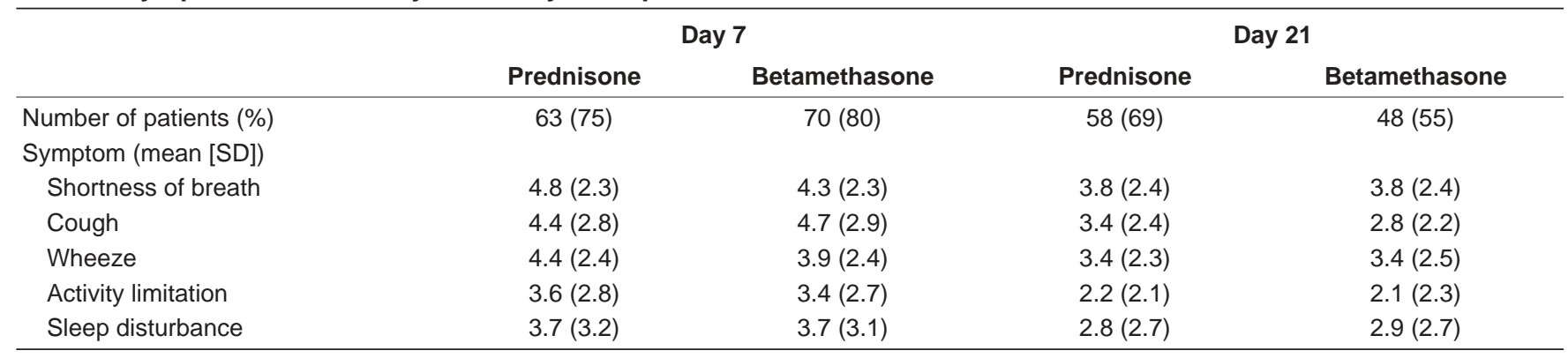

*10-point scale: 1 equals absence of the symptom, 10 equals most severe symptom

\section{DISCUSSION}

Although oral and intramuscular corticosteroids for the treatment of acute exacerbations of asthma after discharge from the ED have been shown to be effective, there are few studies involving direct comparisons between the two regimens. Hoffman and Fiel (9) compared injected methylprednisolone sodium acetate $80 \mathrm{mg}$ with oral prednisone in 17 patients with acute asthma and found no difference in relapse at seven days. In 1998, a year after the initiation of the present study, Schuckman et al (11) reported a trend toward a reduced relapse rate at seven days $(9.0 \%$ versus $14.5 \%)$ in 154 patients discharged from the ED for acute asthma given a single dose of intramuscular triamcinolone $40 \mathrm{mg}$ versus five days of prednisone. Our trial with 171 patients is the largest study directly comparing intramuscular with oral corticosteroids for acute exacerbations of asthma after discharge from the ED.

We found a reduced relapse rate at day 7 in patients given intramuscular betamethasone compared with those given prednisone, although the results were not statistically significant. At the time of completion of our trial, Rowe et al (15) reported that the addition of inhaled budesonide to a short course of prednisone in patients discharged from the ED for acute asthma significantly reduced the relapse rate at 21 days. In this study, at baseline, the patients in the prednisone group were more likely to be on maintenance inhaled corticosteroids (64\% versus $46 \%$ ), and this may have resulted in a decreased relapse rate in the prednisone group, thus reducing the likelihood of finding a statistically significant difference. On the other hand, the higher use of inhaled corticosteroids and the longer duration of asthma in the prednisone group might suggest a more severe subset of asthma patients and, therefore, a higher probability of relapse; however, other markers of severity (previous oral corticosteroids, ED visits, hospitalizations and intensive care admissions) between the two groups were not significantly different.

The finding of a reduced relapse rate at day 7 with intramuscular corticosteroid, although not statistically significant, is similar to the results of Schuckman et al (11). Although sizable numbers of patients were recruited (154 patients in the study by Schuckman et al and 171 patients in the present study), both studies might have been limited by the small sample size. However, if our results are combined with
TABLE 6

Peak flows for weeks 1 and 3 of patients with acute exacerbations of asthma

\begin{tabular}{lcc}
\hline & Week 1 & Week 3 \\
\hline Prednisone $^{*}$ & $60(71 \%)$ & $40(48 \%)$ \\
PEFR (L/min) (mean [SD]) & $369(111)$ & $400(114)$ \\
Betamethasone* $^{*}$ & $63(72 \%)$ & $40(46 \%)$ \\
PEFR (L/min) (mean [SD]) & $356(96)$ & $375(91)$ \\
\hline
\end{tabular}

${ }^{*}$ Nonrelapsed patients with data available. Mean peak flow calculated from the available best morning and evening readings. PEFR Peak expiratory flow rate

those of Schuckman et al (11), the relapse rate at day 7 achieves statistical significance $(\mathrm{P}=0.05)$, favouring intramuscular corticosteroid. Adding the 17 patients from Hoffman and Fiel (9) reduces the $\mathrm{P}$ value to 0.03 . Analysis of the aggregate studies suggests that intramuscular corticosteroid may be more effective than oral prednisone in preventing the relapse of acute exacerbations of asthma at day 7.

At day 21, there was no difference in relapse rate between the two groups. This would suggest that if intramuscular betamethasone was effective, it would only protect against early relapse. This may reflect the pharmacokinetics of betamethasone, which has a half-life of 36 to $72 \mathrm{~h}$ when given orally. When given intramuscularly, the halflife and duration of action are less well described. The $12 \mathrm{mg}$ dose of betamethasone was chosen to maximize the anti-inflammatory effect and minimize pain at the injection site. This dose might have been low, and a larger dose might have shown a sustained reduction in relapse rate at 21 days. Alternatively, 21 days after an exacerbation, the maintenance medications, environmental conditions and underlying control may become more important in determining the tendency to relapse - hence, the finding of similar relapse rates further from the original exacerbation.

Our relapse rates in the prednisone group (25\% and 31\%) were higher than those reported in previous studies. At days 7 to 14 , relapse rates between $10 \%$ and $17 \%$ have been reported $(1,8,16)$; at day 21 , the rates range from $20 \%$ to $25 \%$ $(1,4)$. In the inhaled budesonide study, Rowe et al $(15)$ found a relapse rate of $24.5 \%$ at day 21 in patients given only prednisone. 
A selection bias may account for the higher relapse rate because we relied on ED physicians to refer patients. A review of ED records from the two hospitals over the study period revealed that we were able to enrol only $6 \%$ of patients treated for acute asthma. Some of those not referred presumably met the exclusion criteria, but it is likely that a large percentage of eligible patients were not enrolled. Compared with the patients in the inhaled budesonide study by Rowe et al (15), patients in the present study reported a higher prevalence of past ED treatment ( $94 \%$ versus 59\%), past hospitalizations (61\% versus 38\%) and previous use of oral corticosteroids (77\% versus $30 \%)$. Compared with the study by Chapman et al (1), our patients reported a higher prevalence of past hospitalizations (61\% versus 34\%) and previous use of oral corticosteroids (77\% versus 30\%). Our study population appears to include a higher percentage of patients with worse indexes of underlying control and compliance.

It is important to note that, in practice, only a prescription for prednisone is given at the time of discharge from the ED. In the present study, we provided the prednisone that presumably would lead to higher compliance and reduced relapse. Thus, the relapse rate in the prednisone group is probably an underestimate of what occurs in actual clinical practice.

There are a number of limitations of the present study. As noted earlier, our study population represented approximately $6 \%$ of the patients treated in the ED for asthma during the study period and, therefore, may not be representative of all patients with acute asthma. Our patients had high rates of previous ED visits, hospitalizations and previous oral corticosteroid use, which suggests a more severe subset of asthma patients. Secondly, discharge instructions were not standardized by protocol. Third, relapse was assessed by telephone contact only. We did not perform in-person assessments or review all medical records to ensure that those patients who reported being improved had not relapsed.

\section{CONCLUSIONS}

This study was designed as a pilot study to detect major differences between treatment with betamethasone and prednisone. Further studies with a larger number of patients are needed to confirm the proposed advantage of an intramuscular corticosteroid to prevent the relapse of acute asthma.

Our study suggests that the administration of a single dose of intramuscular betamethasone $12 \mathrm{mg}$ compared with oral prednisone after ED treatment of acute asthma is safe and may lead to an improved outcome at day 7. Although the relapse rates between the two groups were equivalent at day 21, the ability to prevent early relapse would provide a window of opportunity to optimize the outpatient management of asthma. Close follow-up with a physician after ED treatment, education and the use of inhaled corticosteroids may prevent subsequent relapse. In selected ED patients with a high risk for relapse and poor compliance, a single dose of intramuscu- lar betamethasone after ED treatment for acute asthma may prove to be an effective alternative to a prescription for prednisone.

ACKNOWLEDGEMENTS: Supported by a grant by Research and Development of the University of Calgary, Calgary, Alberta. Betamethasone (Celestone Soluspan) was supplied by Schering Canada Inc, Pointe-Claire, Quebec. The purchase of peak flow meters was provided by Boehringer Ingelheim (Canada) Limited, Burlington, Ontario. The authors thank the staff of the emergency and respiratory therapy departments of the Rockyview General Hospital and the Peter Lougheed Center for their support and contribution to this study, and Mrs Diane Phillips-Reeder and the department of pharmacy for their preparation of the study medications.

\section{REFERENCES}

1. Chapman KR, Verbeek PR, White JG, Rebuck AS. Effect of a short course of prednisone in the prevention of early relapse after the emergency room treatment of acute asthma. N Engl J Med 1991;324:788-94.

2. Fiel SB, Swartz MA, Glanz K, Francis ME. Efficacy of short-term corticosteroid therapy in outpatient treatment of acute bronchial asthma. Am J Med 1983;75:259-62.

3. Rowe BH, Spooner CH, Ducharme FM, Bretzlaff JA, Bota GW. The effectiveness of corticosteroids in the treatment of acute exacerbations of asthma: a meta-analysis of their effect on relapse following acute assessment. In: Cochrane Review on CD-ROM, issue 3. Oxford: Update Software, 1998.

4. Emerman CL, Cydulka RK. Factors associated with relapse after emergency department treatment for acute asthma. Ann Emerg Med 1995;26:6-11.

5. Dekker FW, Dieleman FE, Kaptein AA, Mulder JD. Compliance with pulmonary medication in general practice. Eur Respir J 1993;6:886-90.

6. Saunders CE. Patient compliance in filling prescriptions after discharge from the emergency department. Am J Emerg Med 1987;5:283-6.

7. Thomas EJ, Burstin HR, O’Neil AC, Orav EJ, Brennan TA. Patient non-compliance with medical advice after the emergency department visit. Ann Emerg Med 1996;27:49-55.

8. McNamara RM, Rubin JM. Intramuscular methylprednisolone acetate for the prevention of relapse in acute asthma. Ann Emerg Med 1993;22:1829-35.

9. Hoffman IB, Fiel SB. Oral vs repository corticosteroid therapy in acute asthma. Chest 1988;93:11-3.

10. Green SS, Lamb GC, Schmitt S, Kaufman J. Oral versus repository corticosteroid therapy after hospitalization for treatment of asthma. J Allergy Clin Immunol 1995;95:15-22.

11. Schuckman H, Dejulius DP, Blanda M, Gerson LW, DeJulius AJ, Rajaratnam M. Comparison of intramuscular triamcinolone and oral prednisone in the outpatient treatment of acute asthma: a randomized controlled trial. Ann Emerg Med 1998;31:333-8.

12. Annual Demographic Statistics 1996. Ottawa: Statistics Canada, 1996.

13. Beveridge RC, Grunfeld AF, Hodder RV, Verbeek PR, for the Canadian Association of Emergency Physicians and the Canadian Thoracic Society Asthma Advisory Committee. Guidelines for the emergency management of asthma in adults. CMAJ 1996;155:25-37.

14. Hardman JG, Gilman AG, Limbird LE, eds. Goodman and Gilman's The Pharmacological Basis of Therapeutics, 9th edn. New York: McGraw-Hill, 1996:1466.

15. Rowe BH, Bota GW, Fabris L, Therrien SA, Milner RA, Jacono J. Inhaled budesonide in addition to oral corticosteroids to prevent asthma relapse following discharge from the emergency department: a randomized controlled trial. JAMA 1999;281:2119-26.

16. Emerman CL, Woodruff PG, Cydulka RK, Gibbs MA, Pollack CV Jr, Camargo CA Jr, for the Multicenter Asthma Research Collaboration investigators. Prospective multicenter study of relapse following treatment for acute asthma among adults presenting to the emergency department. Chest 1999;115:919-27. 


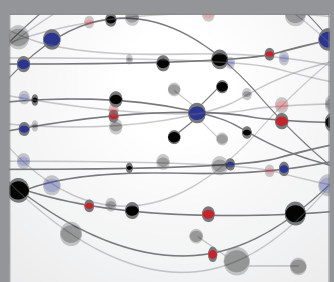

The Scientific World Journal
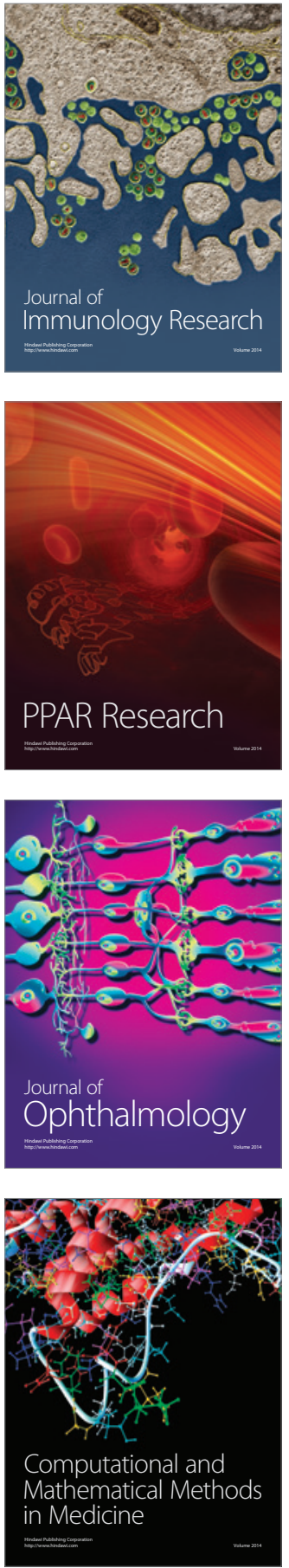

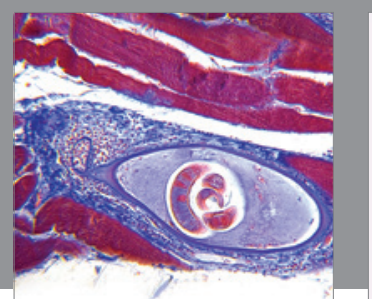

Gastroenterology Research and Practice

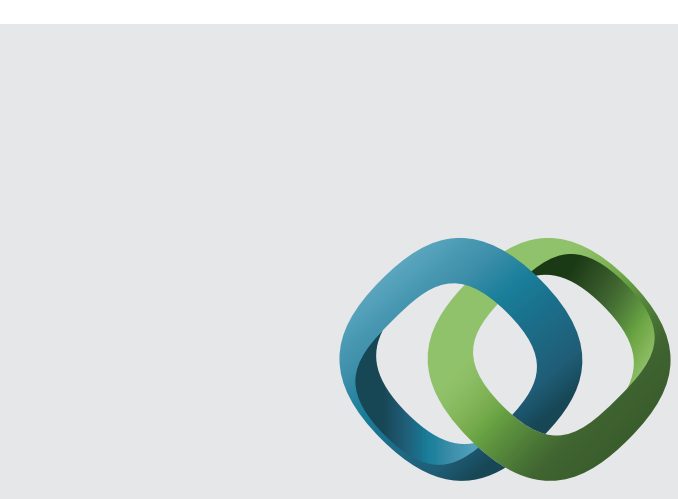

\section{Hindawi}

Submit your manuscripts at

http://www.hindawi.com
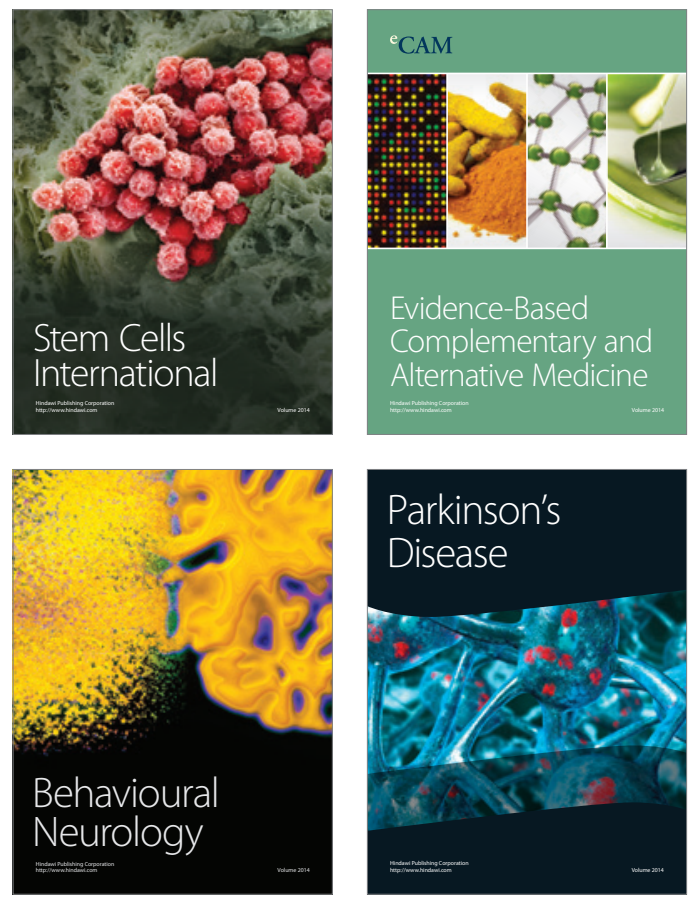
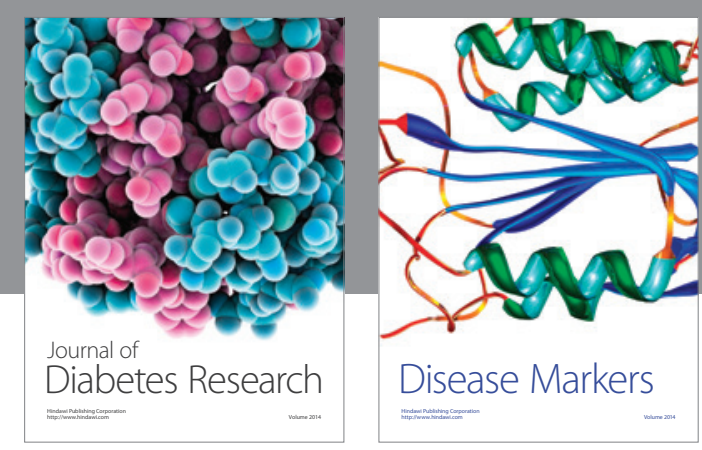

Disease Markers
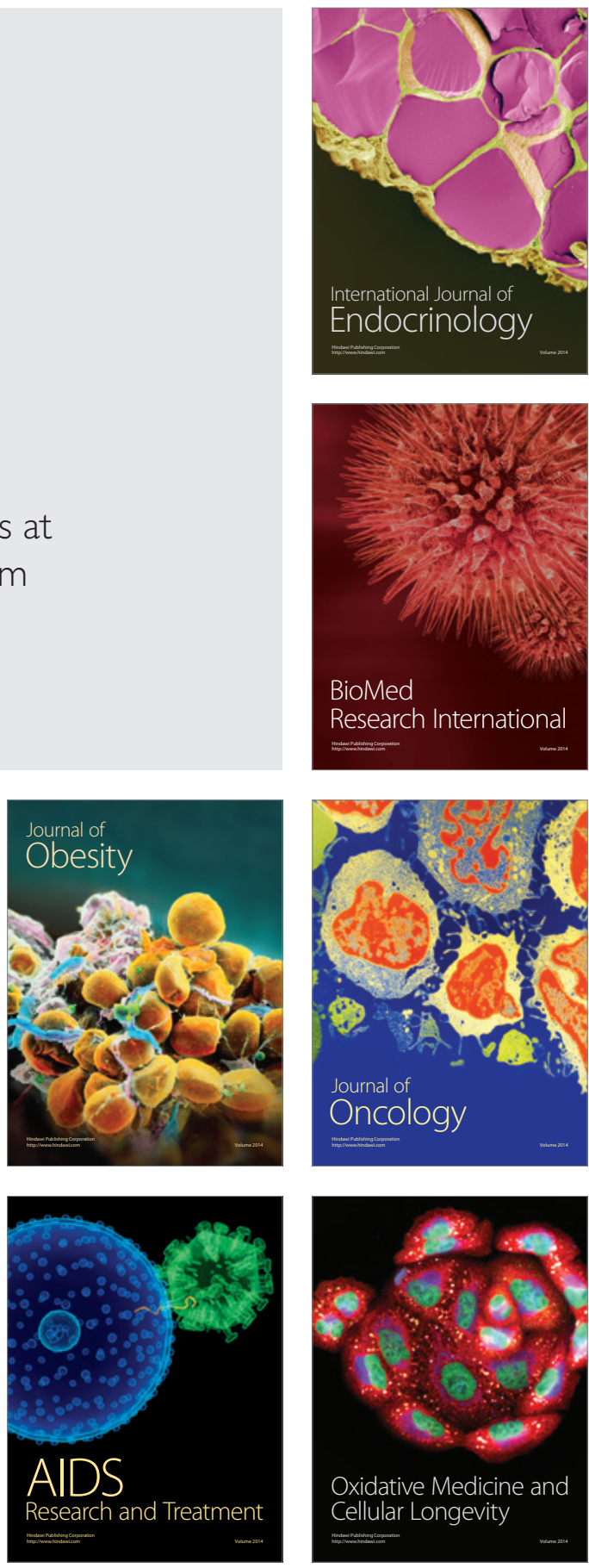